\title{
PERAN WANITA TANI DALAM PENGAMBILAN KEPUTUSAN USAHATANI
}

\author{
Shenny Oktoriana*, Anita Suharyani \\ Program Studi Agribisnis, Fakultas Pertanian, Universitas Tanjungpura \\ Jl. Prof. Dr. H. Hadari Nawawi, Pontianak 78124 \\ *Corresponding author: shenny.oktoriana@faperta.untan.ac.id
}

\begin{abstract}
Male farmers are considered as the main subject in managing a farm. This condition has an impact on almost of farmer capacity-building programs involving only male farmers. In fact, the role of women farmers in managing their farming is inseparable. Therefore, the study aims to measure the level of the role of women farmers in decision-making in farming activities. The research was conducted in Limbung Village of Kubu Raya District, which involved 64 respondents. Data were collected through interviews with respondents and were analyzed descriptively. The result of the research showed that women farmers who had a higher level of activeness in the women farmers group tend to have more influence in the decision making in their farming activity, compared to the women farmers with a lower level of activeness, although the final decisions still made by men. Therefore women farmers' involvement in farmers' capacity-building programs is an essential matter for agricultural development.
\end{abstract}

Keywords: decision making, farmers' group, women farmers

\begin{abstract}
Abstrak: Selama ini petani pria dianggap sebagai subjek utama dalam mengelola usahatani. Hal tersebut berdampak pada hampir seluruh program peningkatan kapasitas petani hanya melibatkan petani pria sebagai sasarannya. Kenyataannya dalam mengelola usahatani sangat terkait dengan peran wanita tani. Tujuan penelitian adalah mengukur tingkat peran wanita tani dalam pengambilan keputusan pada aktivitas usahatani. Penelitian dilakukan di Desa Limbung Kabupaten Kubu Raya, yang melibatkan 64 orang responden wanita tani. Data dikumpulkan melalui wawancara terhadap responden, dan dianalisis secara deskriptif. Hasil penelitian menunjukkan bahwa wanita tani yang lebih aktif dalam kelompok tani memiliki peran yang lebih tinggi dalam pengambilan keputusan usahatani, dibandingkan wanita tani yang tidak aktif, walaupun keputusan akhir dalam usahatani masih ditentukan oleh pria. Oleh karena itu, keterlibatan wanita tani dalam program-program pengembangan kapasitas petani sangat penting dalam pembangunan pertanian.
\end{abstract}

Kata kunci: pengambilan keputusan, kelompok tani, wanita tani

\section{PENDAHULUAN}

Usahatani merupakan suatu usaha yang dijalankan oleh kepala keluarga beserta anggota keluarganya dimana setiap anggota keluarga dapat terlibat langsung maupun tidak langsung. Umumnya kepala keluarga merupakan pemegang peran utama dalam usahatani, namun kenyataannya istri juga memiliki peran yang tidak kalah penting. Suami dan istri melakukan kerja sama dalam mengelola manajemen keuangan usahatani, bahkan istri memberikan kontribusi $11,3 \%$ terhadap pendapatan total rumah tangga (Puspitasari et al., 2013). Dalam hal pelaksanaan usahatani, wanita tani juga memegang peranan yang lebih dominan dibandingkan pria terutama dalam pengolahan hasil pertanian dan pemasaran (Astuti et al., 2011; Lesmana, 2005). Terdapat kelompok tani yang hanya beranggotakan wanita tani pada beberapa daerah di Indonesia, 
yaitu para istri yang ikut secara aktif bekerja di lahan usahatani.

Setiap keputusan yang diambil dalam usahatani sebagai usaha keluarga, juga dipengaruhi oleh peran petani wanita sebagai bagian dari usaha tani maupun bagian dari keluarga, walaupun umumnya yang berperan mengambil keputusan akhir adalah kepala keluarga (petani pria). Penelitian terdahulu menunjukkan bahwa wanita tani tidak hanya bertanggung jawab terhadap urusan rumah tangga, tetapi juga berpartisipasi aktif dalam aktivitas on farm, off farm, maupun non farm, demikian juga dalam proses pengambilan keputusan (AARD-IDRC, 1991).

Kondisi saat ini menunjukkan kaum pria masih mendominasi dalam kegiatan kelompok tani maupun kegiatan penyuluhan pertanian, dimana kegiatan tersebut bertujuan meningkatkan kapasitas petani dalam mengelola usahataninya. Padahal wanita tani juga ikut serta dalam kegiatan pertanian secara aktif, namun kesempatannya untuk ikut dalam kegiatan penyuluhan lebih kecil dibandingkan pria (Karaya et al., 2013; Manfre et al., 2013). Pada negara-negara berkembang wanita memiliki peran yang signifikan dalam pertanian, dengan rata-rata $43 \%$ angkatan kerja pertanian adalah wanita (SOFA-Team dan Doss, 2011). Produksi pada usahatani yang melibatkan wanita tani dapat mengalami peningkatan 20-30\%, dan meningkatkan PDB sektor pertanian pada negara berkembang sebesar 2,5-4\% menurut (FAO, 2011).

Berjalannya proses sosial di lingkungan pedesaan saat ini menunjukkan mulai adanya kelompok tani yang beranggotakan wanita tani. Melalui kelompok tani yang merupakan wujud dari kelompok sosial, maka akan terjadi perubahan pada diri para wanita tani, terutama dilihat dari segi wawasannya. Sehingga dalam pengambilan keputusan usahatani peran wanita diperkirakan akan semakin meningkat. Berdasarkan hal tersebut, maka perlu dilakukan suatu kajian yang berkaitan dengan peran wanita tani dalam pengambilan keputusan usahatani, terutama bagi wanita tani yang tergabung dalam kelompok tani. Hasil kajian terhadap peran wanita tani tersebut selanjutnya dapat menjadi dasar kebijakan dalam program peningkatan kapasitas petani yang lebih melibatkan wanita tani sebagai pengelola usahatani, tidak hanya melibatkan petani pria sebagai sasaran utamanya.

\section{METODE PENELITIAN}

Penelitian dilaksanakan di Desa Limbung, Kecamatan Sungai Raya, Kabupaten Kubu Raya, dimana pada desa tersebut terdapat kelompok tani khusus untuk wanita tani. Anggota kelompok tersebut adalah wanita tani yang aktif bertani di lahan gambut. Disamping itu juga terdapat wanita tani yang aktif bekerja di lahan usahatani namun tidak tergabung dalam kelompok tani. Sehingga dapat dilakukan perbandingan antara wanita tani yang aktif dalam kelompok tani terhadap wanita tani yang tidak tergabung dalam kelompok tani.

Pengambilan sampling responden dengan metode stratified sampling dengan menentukan sub populasi (Daniel, 2005). Pengambilan sampel terlebih dulu menentukan criteria populasi. Dalam hal ini criteria populasi tersebut yaitu :

1) Wanita tani yang aktif bekerja di lahan usahatani.

2) Wanita tani yang tergabung dalam kelompok tani maupun yang tidak tergabung dalam kelompok tani.

Berdasarkan kategori tersebut diperoleh wanita tani di lokasi penelitian sejumlah 64 orang. Selanjutnya dikelompokkan menjadi 26 orang wanita tani yang tergabung dalam kelompok tani, serta 38 orang wanita tani yang tidak tergabung dalam kelompok tani.

Variabel yang diukur yaitu peran petani wanita dalam pengambilan keputusan. Peran wanita tani dalam pengambilan keputusan usahatani dalam penelitian ini ditinjau dari beberapa tahap, sesuai dengan teori Simon Herbert yang dikenal sebagai Simon's Model of Decision Making (Simon, 1993). Dalam teori tersebut dikemukakan bahwa tahap pengambilan keputusan melalui tahapan yang terdiri dari intelligence phase, design phase, serta choice phase.

Untuk melihat peran wanita tani dalam pengambilan keputusan usahatani dilakukan pengukuran terhadap dominasi dan peran petani wanita dalam tiga tahap pengambilan keputusan usahatani tersebut. Ketiga fase pengambilan keputusan diukur pada setiap keputusan yang dibuat dalam usahatani, yang didasarkan pada unsur pokok usahatani yaitu 
modal, lahan, tenaga kerja, dan pengelolaan usahatani (Hernanto, 1996). Kemudian dari unsur-unsur usahatani tersebut diuraikan menjadi 11 jenis keputusan, yaitu dari lima dari unsur modal (sumber modal, penggunaan benih, penggunaan pupuk, penggunaan pestisida, dan penggunaan peralatan pertanian), satu dari unsur lahan (luas lahan yang digarap.), dua dari unsur tenaga kerja (alokasi tenaga kerja serta upah tenaga kerja) dan tiga jenis keputusan dari unsur pengelolaan usahatani (waktu panen, harga jual komoditi, serta pemasaran hasil panen).

Penilaian peran wanita tani dalam pengambilan keputusan didasarkan penjelasan deskriptif dari responden. Peran wanita tani dikategorikan menjadi 1) tinggi jika tahap keputusan didominasi wanita tani, 2) sedang jika tahap keputusan dilakukan oleh petani pria dan wanita secara seimbang, dan 3) rendah jika tahap keputusan didominasi petani pria.

Berdasarkan hasil jawaban responden tersebut kemudian dilakukan penjumlahan sebaran tingkat peran wanita tani pada masingmasing tahapan keputusan untuk setiap unsur usahatani, apakah didominasi oleh jawaban tinggi, sedang dan rendah. Dominasi tersebut dilihat dari persentase jumlah responden yang menjawab tinggi, sedang atau rendah, dari total keseluruhan responden. Tingkat pengambilan keputusan dengan persentase tertinggi menjadi penentu tingkat peran wanita tani dalam setiap tahap pengambilan keputusan.

\section{HASIL DAN PEMBAHASAN}

Sebagai fase pertama dalam proses pengambilan keputusan, fase intelligence merupakan tahap identifikasi permasalahan dan pengumpulan informasi terkait dengan hal yang akan diputuskan. Hasil analisis menunjukkan peran wanita tani di fase ini tergolong tinggi pada wanita tani yang menjadi anggota kelompok tani. Wanita tani yang tidak tergabung dalam kelompok tani didominasi oleh tingkat peran yang sedang pada tahap ini. Hal ini disebabkan wanita tani yang terlibat dalam kelompok tani cenderung memiliki peluang untuk melakukan pencarian informasi terkait hal-hal dalam usahatani yang akan diputuskan. Baik dalam hal adanya media untuk bertanya melalui kegiatan kelompok, maupun adanya kegiatan pertemuan yang meningkatkan intensitas interaksi antar wanita tani.

Peran wanita tani yang menjadi anggota kelompok pada tahap intelligence tergolong tinggi pada pencarian informasi untuk 6 dari 11 jenis keputusan yang diambil dalam usahatani, yaitu penggunaan modal usahatani, penggunaan peralatan pertanian, luas lahan digarap, penentuan waktu panen, penentuan harga jual komoditi, dan pemasaran hasil.

Tabel 1. Tingkat peran wanita tani dalam fase intelligence berdasarkan dominasi responden

\begin{tabular}{|c|c|c|c|c|c|}
\hline \multirow{3}{*}{$\begin{array}{c}\text { Unsur Pokok } \\
\text { Usahatani }\end{array}$} & \multirow{3}{*}{ Jenis Keputusan } & \multicolumn{4}{|c|}{ Tingkat Dominasi Peran } \\
\hline & & \multicolumn{2}{|c|}{ Anggota Kelompok } & \multicolumn{2}{|c|}{ Non Anggota Kelompok } \\
\hline & & Tingkat & $(\%)^{1}$ & Tingkat & $(\%)^{1}$ \\
\hline \multirow[t]{5}{*}{ Modal } & Penggunaan modal & Tinggi & 42,3 & Sedang & 42,1 \\
\hline & Penggunaan benih & Sedang & 34,6 & Tinggi & 52,6 \\
\hline & Penggunaan pupuk & Sedang & 38,5 & Sedang & 55,3 \\
\hline & Penggunaan pestisida & Sedang & 42,3 & Sedang & 55,3 \\
\hline & $\begin{array}{l}\text { Penggunaan peralatan } \\
\text { pertanian }\end{array}$ & Tinggi & 34,6 & Sedang & 44,7 \\
\hline Lahan & Luas lahan ditanami & Tinggi & 42,3 & Sedang & 71,1 \\
\hline \multirow[t]{2}{*}{ Tenaga kerja } & Alokasi tenaga kerja & Sedang & 42,3 & Sedang & 55,3 \\
\hline & Upah tenaga kerja & Rendah & 38,4 & Tinggi & 36,8 \\
\hline \multirow[t]{4}{*}{ Pengelolaan } & Waktu panen & Tinggi & 53,8 & Sedang & 42,1 \\
\hline & Harga jual komoditi & Tinggi & 46,2 & Rendah & 65,8 \\
\hline & Pemasaran hasil panen & Tinggi & 38,5 & Sedang & 47,4 \\
\hline & Rata-rata Total & Tinggi & 37,8 & Sedang & 42,1 \\
\hline & & $80^{\circ}$ & omina & & \\
\hline
\end{tabular}


Informasi yang dicari oleh petani wanita cenderung fokus kepada hal-hal yang terkait dengan finansial usahatani, yaitu mencari informasi terkait modal, upah tenaga kerja, harga jual serta saluran pemasaran hasil panen mereka. Sejalan dengan penelitian lain bahwa wanita tani yang tergabung dalam kelompok tani mengalami peningkatan akses terhadap sumberdaya yang mereka butuhkan untuk usahataninya salah satunya aspek finansial (Othman et al., 2020).

Aktivitas kelompok wanita tani di Desa Limbung berupa kegiatan pertemuan rutin. Kegiatan yang juga berupa pertemuan arisan atau pengajian ini, biasanya diisi dengan diskusi informal terkait perkembangan usahatani mereka antara lain tentang perkembangan harga komoditi, tujuan pemasaran yang memberikan harga lebih tinggi, perkembangan harga upah buruh tani, serta teknik budidaya yang lebih baik. Melalui forum tersebutlah terjadi pertukaran informasi antar wanita tani. Hal ini juga menunjukkan wanita tani yang aktif dalam kelompok tanilebih semangatmencari informasi terkait hal-hal tersebut. Informasi diperoleh dari sesama anggota kelompok melalui forum pertemuan kelompok, serta melalui kenalan dari luar desa.

Wanita tani yang tidak tergabung dalam kelompok tani secara keseluruhan memiliki peran yang tergolong sedang. Peran yang tergolong tinggi hanya pada pencarian informasi penggunaan benih dan tingkat upah tenaga kerja. Akses pada sumber informasi sangat terbatas yaitu dari rekan sesama petani yang letak lahannya bersebelahan atau dari tetangga yang juga petani.

Fase keputusan selanjutnya adalah design, yaitu melakukan pengembangan terhadap alternatif dalam menyelesaikan masalah, melalui eksplorasi terhadap peluang yang dihadapi. Peran wanita tani pada fase ini menunjukkan pola yang sama dengan tahap intelligence, yaitu cukup tinggi untuk wanita tani yang menjadi anggota kelompok tani, dan tergolong sedang untuk wanita tani yang tidak tergabung dalam kelompok tani. Hal ini disebabkan wanita tani yang terlibat dalam kelompok tani memiliki intensitas yang tinggi untuk berinteraksi antar sesama pelaku usahatani, sehingga dapat berbagi pengalaman keberhasilan dan kegagalan menjalankan berbagai kegiatan usahatani.

Peran wanita tani yang aktif dalam kelompok tani pada tahap design cenderung dominan pada unsur penggunaan modal, penggunaan benih, penggunaan pupuk penggunaan pestisida, serta penggunaan lahan dan waktu panen. Petani wanita berkontribusi tinggi dalam mengatur modal usahatani, dari lima jenis keputusan terkait modal hanya terdapat satu jenis keputusan dimana peran wanita tani tergolong sedang.

Hal tersebut menunjukkan wanita tani lebih mendominasi dalam aspek finansial usahatani (Puspitasari et al., 2013).

Tabel 2. Tingkat peran wanita tani dalam fase design berdasarkan dominasi responden

\begin{tabular}{|c|c|c|c|c|c|}
\hline \multirow{3}{*}{$\begin{array}{l}\text { Unsur Pokok } \\
\text { Usahatani }\end{array}$} & \multirow{3}{*}{ Jenis Keputusan } & \multicolumn{4}{|c|}{ Tingkat Dominasi Peran } \\
\hline & & \multicolumn{2}{|c|}{ Anggota Kelompok } & \multicolumn{2}{|c|}{ Non Anggota Kelompok } \\
\hline & & Tingkat & $(\%)^{1}$ & Tingkat & $(\%)^{1}$ \\
\hline \multirow[t]{5}{*}{ Modal } & Penggunaan modal & Tinggi & 46,2 & Tinggi & 39,4 \\
\hline & Penggunaan benih & Tinggi & 46,2 & Tinggi & 47,4 \\
\hline & Penggunaan pupuk & Tinggi & 42,3 & Sedang & 55,3 \\
\hline & Penggunaan pestisida & Tinggi & 38,5 & Sedang & 55,3 \\
\hline & Penggunaan peralatan pertanian & Sedang & 34,6 & Sedang & 47,4 \\
\hline Lahan & Luas lahan ditanami & Tinggi & 46,2 & Sedang & 63,2 \\
\hline \multirow[t]{2}{*}{ Tenaga kerja } & Alokasi tenaga kerja & Sedang & 38,5 & Sedang & 44,7 \\
\hline & Upah tenaga kerja & Rendah & 46,2 & Tinggi & 42,1 \\
\hline \multirow[t]{4}{*}{ Pengelolaan } & Waktu panen & Tinggi & 46,2 & Sedang & 42,1 \\
\hline & Harga jual komoditi & Sedang & 50,0 & Rendah & 44,7 \\
\hline & Pemasaran hasil panen & Rendah & 46,2 & Sedang & 42,1 \\
\hline & Rata-rata Total & Tinggi & 37,8 & Sedang & 43,5 \\
\hline Sumber & $\begin{array}{l}\text { rsentase jumlah } \\
\text { a primer, } 2017\end{array}$ & & $\operatorname{mina}$ & & \\
\hline
\end{tabular}


Peran wanita yang non anggota kelompok tani hanya tinggi pada tiga hal, yaitu penggunaan modal, penggunaan benih dan upah tenaga kerja.

Keputusan terkait penggunaan modal, penggunaan benih, penggunaan pupuk penggunaan pestisida, serta penggunaan lahan dan waktu panen ditentukan oleh wanita tani, dan hanya sedikit responden yang melibatkan suami dalam pengambilan keputusan. Usahatani sayuran sebagian besar dikelola wanita tani, Pria terutama bertugas untuk mempersiapkan lahan saat akan mulai penanaman.

Wanita tani yang tergabung dalam kelompok tani memiliki interaksi antar petani yang lebih tinggi. Kesempatan tersebut dimanfaatkan untuk saling berbagi pengetahuan dan informasi terkait usahatani, dan menjadi media bagi masing-masing wanita tani untuk mengeksplorasi peluang alternatif yang paling baik sehingga dapat diputuskan alternatif yang akan diambil sebagai keputusan akhir pada tahap selanjutnya. Sehingga wanita tani tersebut memiliki kemampuan untuk menjadi pengelola dalam usaha tani mereka masingmasing.

Fase terakhir dalam pengambilan keputusan yaitu fase choice, dimana dilakukan evaluasi terhadap setiap alternatif yang dikembangkan pada tahap design, kemudian memilih satu diantara alternatif yang ada. Alternatif yang dipilih tersebut merupakan keputusan akhir yang diperoleh dari ketiga tahap yang telah dilalui.

Peran wanita tani yang menjadi anggota kelompok tani pada tahap choice secara umum terkategori pada tingkat peran tinggi. Wanita tani yang tidak menjadi anggota kelompok cenderung sedang tingkat perannya. Peran wanita tani yang aktif dalam kelompok tani pada tahap choice cenderung dominan pada 8 dari 11 jenis keputusan usahatani. Kedelapan hal tersebut yaitu dalah unsur modal yang terdiri dari kegiatan penggunaan modal usahatani, penggunaan benih, penggunaan pupuk, penggunaan pestisida.

Peran wanita tani yang tergabung dalam kelompok tani juga tinggi dalam keputusan luas lahan yang ditanami, alokasi tenaga kerja serta harga jual komoditi. Hal tersebut menunjukkan wanita yang tergabung dalam kelompok tani cenderung mendapatkan kepercayaan dari suami untuk berperan dalam mengambil keputusan usahataninya. Hal ini karena tingginya wawasan wanita tani yang terlibat dalam kelompok, serta karena wanita tani yang menjadi anggota kelompok lebih tinggi intensitasnya dalam melakukan kegiatan rutin di lahan usahatani bersama kepala keluarga.

Hal tersebut sesuai dengan hasil penelitian yang menunjukkan bahwa semakin tinggi curahan waktu wanita tani dalam usahataninya maka semakin kuat posisinya dalam pengambilan keputusan usahatani (Lesmana, 2005).

Tabel 3. Persentase jumlah responden berdasarkan tingkat peran wanita tani dalam pengambilan keputusan pada fase Choice

\begin{tabular}{llllll}
\hline \multirow{2}{*}{$\begin{array}{c}\text { Unsur Pokok } \\
\text { Usahatani }\end{array}$} & \multicolumn{1}{c}{ Jenis Keputusan } & \multicolumn{3}{c}{ Tingkat Dominasi Peran } \\
\cline { 3 - 5 } & & Anggota Kelompok & Non Anggota Kelompok \\
\cline { 2 - 5 } Modal & Penggunaan modal & Tingkat & $(\%)^{1}$ & Tingkat & $(\%)^{1}$ \\
& Penggunaan benih & Tinggi & 46,2 & Sedang & 63,2 \\
& Penggunaan pupuk & Tinggi & 46,5 & Sedang & 57,9 \\
& Penggunaan pestisida & Tinggi & 42,3 & Rendah & 63,2 \\
& Penggunaan peralatan & Tinggi & 42,3 & Sedang & 55,3 \\
& pertanian & & & & 55,3 \\
\hline Lahan & Luas lahan ditanami & Tinggi & 42,3 & Rendah & 60,5 \\
\hline Tenaga kerja & Alokasi tenaga kerja & Tinggi & 38,5 & Sedang & 68,4 \\
& Upah tenaga kerja & Sedang & 42,3 & Sedang & 68,4 \\
\hline Pengelolaan & Waktu panen & Sedang & 46,2 & Sedang & 60,5 \\
& Harga jual komoditi & Tinggi & 38,5 & Sedang & 52,6 \\
& Pemasaran hasil panen & Rendah & 53,8 & Tinggi & 39,5 \\
\hline
\end{tabular}

Keterangan $\quad:{ }^{1}$ Persentase jumlah responden berdasarkan tingkat dominasi

Sumber : Data primer, 2017 


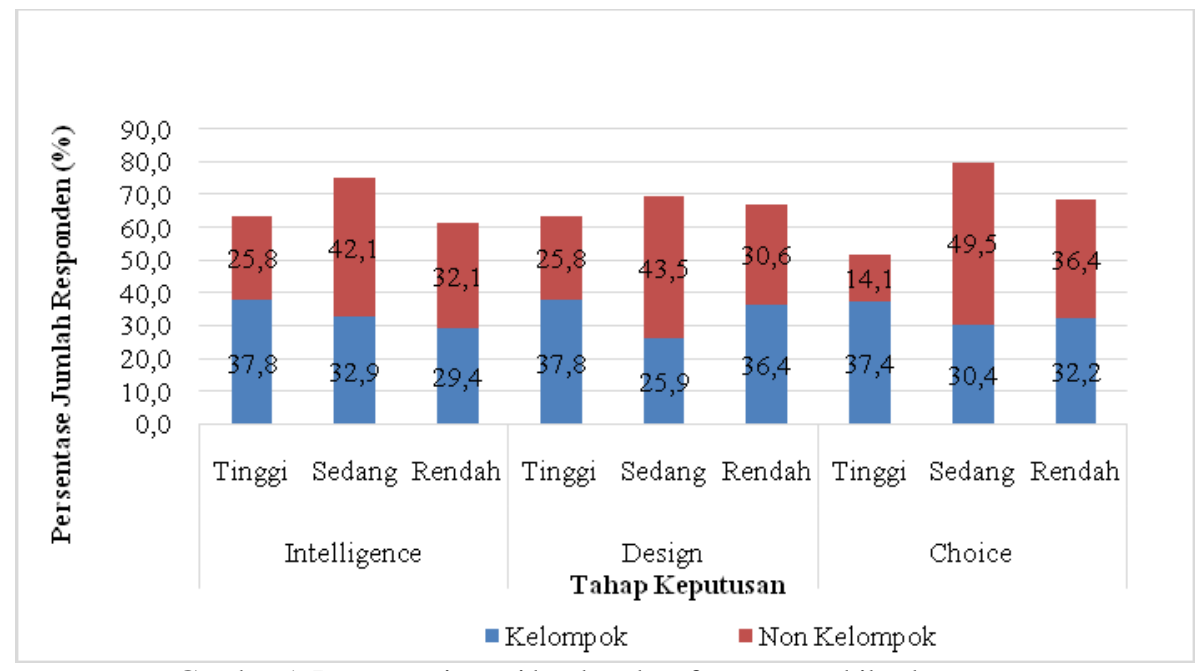

Gambar 1. Peran wanita tani berdasarkan fase pengambilan keputusan Sumber: Data primer, 2017

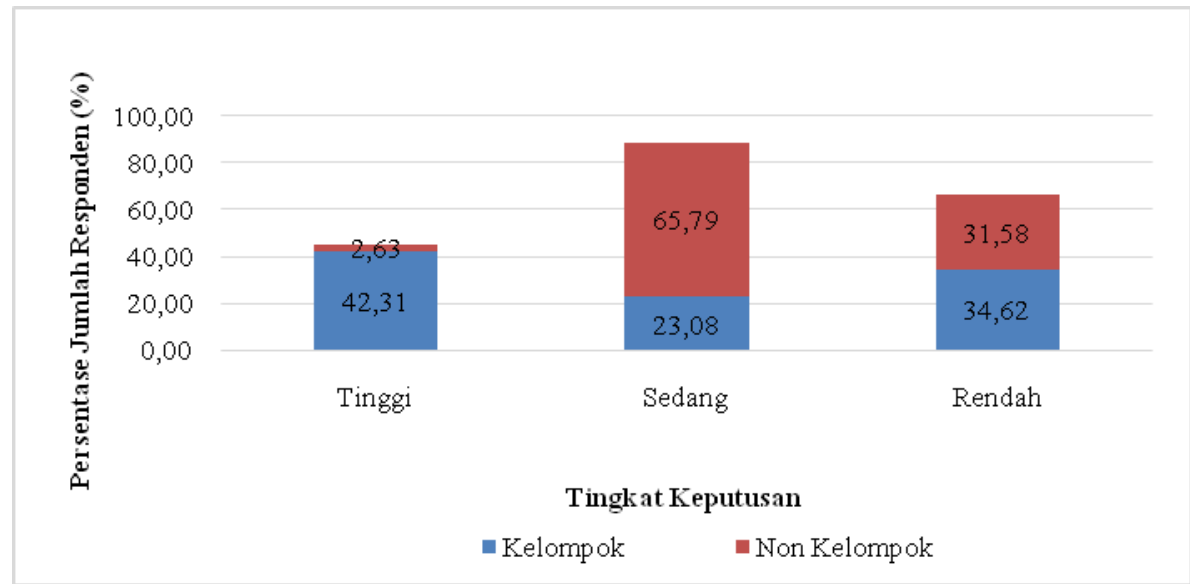

Gambar 2. Tingkat peran wanita tani dalam pengambilan keputusan secara keseluruhan Sumber: Data primer, 2017

Berdasarkan penggambaran secara visual pada Gambar 1 menunjukkan bahwa pada setiap fase pengambilan keputusan peran wanita tani secara keseluruhan menunjukkan dominasi peran tingkat tinggi untuk wanita tani yang tergabung dalam kelompok tani. Wanita tani yang tidak tergabung dalam kelompok tani cenderung didominasi oleh peran tingkat sedang.

Gambar 1 menunjukkan bahwa wanita tani yang menjadi anggota kelompok tani memiliki peran yang lebih penting dalam pengambilan keputusan pada setiap unsur pengelolaan usahatani, dibandingkan wanita tani yang tidak tergabung dalam kelompok tani. Melalui kelompok tani akses wanita tani terhadap peningkatan kapasitas, informasi dan pengetahuan menjadi lebih tinggi, karena lebih besar kesempatannya untuk terlibat dalam kegiatan penyuluhan. Kemudian pada akhirnya usahatani yang dijalankan akan menjadi lebih baik. Hal tersebut sejalan dengan penelitian terdahulu bahwa wanita tani yang tergabung dalam suatu kelompok mendapatkan keuntungan dalam hal tambahan tenaga kerja luar keluarga, akses terhadap penyuluhan pertanian, akses terhadap pendanaan dan pemasaran produk mereka, dukungan sosial dan akses terhadap input yang berkualitas (Karaya et al., 2013). Bahkan lebih jauh, keterlibatan wanita tani dalam kegiatan penyuluhan yang pada umumnya diwadahi oleh kelompok tani, dapat memberikan manfaat dari segi usahatani (peningkatan keterampilan dan produktivitas, menjamin keberlanjutan produk yang berkualitas, menciptakan peluang kerja 
baru bagi wanita dalam usahatani) serta dari segi pembangunan (penguatan ketahanan pangan dan penurunan angka kemiskinan, menghilangkan diskriminasi terhadap wanita, dan memperbaiki asupan nutrisi keluarga) (Manfre et al., 2013). Penelitian lainnya menunjukkan bahwa peran penyuluh menjadi faktor signifikan dalam proses pengambilan keputusan petani (Sari et al., 2016).

Jika jumlah responden wanita tani dikelompokkan berdasarkan tingkat perannya secara keseluruhan menunjukkan bahwa peran wanita tani masih didominasi oleh tingkat sedang, walaupun pada kelompok tersebut didominasi oleh wanita tani yang tidak tergabung dalam kelompok tani. Gambar 2 menunjukkan dalam pengambilan keputusan usahatani belum sepenuhnya didominasi oleh peran wanita. Namun berdasarkan data tersebut juga dapat dilihat kecenderungan lainnya, yaitu wanita tani yang aktif dalam kelompok tani cenderung memiliki peran yang tinggi dalam pengambilan keputusan usahatani.

Hasil analisis sejalan dengan penelitian terdahulu bahwa wanita tani memiliki peran yang cukup besar dalam menjalankan usahatani (Kasmiyati dan Priyanti, 2014; Notoatmojo, 2001). Walaupun demikian, sebagian keputusan akhir tetap berada di tangan petani pria. Sejalan dengan hasil penelitian terdahulu bahwa peran wanita lebih dominan dibandingkan dengan pria dalam aspek aktivitas usahatani, namun partisipasi wanita dalam usahatani lebih rendah dalam aspek kontrol (terutama terhadap lahan, peralatan, dan pemasaran hasil usahatani) dan aspek akses (terutama peluang mendapatkan pelatihan dan informasi pasar) karena kewenangan dan kesempatan paling besar berada pada petani pria (Bhastoni dan Yuliati, 2016).

\section{KESIMPULAN}

Wanita tani yang terlibat dalam kelompok tani cenderung memiliki peran tinggi dalam pengambilan keputusan usahatani, baik dalam fase intelligence, design, maupun choice. Artinya wanita tani yang terlibat dalam kelompok tani lebih aktif terlibat dalam pengambilan keputusan serta mendapatkan kepercayaan yang lebih tinggi dari kepala keluarga sebagai pelaku utama usahatani dalam mengambil keputusan, dibandingkan dengan yang tidak tergabung dalam kelompok tani. Secara keseluruhan pengambilan keputusan usahatani belum sepenuhnya didominasi oleh peran wanita, artinya masih ada peran pria dalam pengambilan keputusan akhir dalam menjalankan usahatani. Namun hal ini menggambarkan bahwa pengelolaan usahatani tidak didominasi oleh petani pria saja, melainkan terdapat kontribusi petani wanita yang cukup tinggi. Oleh karena itu, akan lebih baik jika petani wanita ikut dilibatkan dalam program-program peningkatan kapasitas petani, misalnya melalui kegiatan penyuluhan pertanian, pendampingan dan pembinaan kelompok tani.

\section{DAFTAR PUSTAKA}

AARD-IDRC. (1991). Women in Farming System: An Operation Research and Training Program. IRRI Philipina.

Astuti, U. P., Makruf, E., \& Ishak, A. (2011). Analisis Peran Wanita dalam Rumah Tangga Petani Mendukung Keberhasilan Program SLPTT-PUAP di Bengkulu. Bengkulu: Litbang Pertanian Bengkulu.

Bhastoni, K., \& Yuliati, Y. (2016). Peran wanita tani di atas usia produktif dalam usahatani sayur organik terhadap pendapatan rumah tangga di Desa Sumberejo Kecamatan Batu. Habitat, 26(2), 119-129.

Daniel, M. (2005). Metode Penelitian Sosial Ekonomi. Jakarta: Bumi Aksara.

FAO. (2011). The State of Food and Agriculture 2010-2011. Rome: FAO. Retrieved from http://www.fao.org/ publications/sofa/2010-11/en/

Hernanto, F. (1996). Ilmu Usahatani. Jakarta: Penebar Swadaya.

Karaya, R. N., Onyango, C. A., \& Amudavi, D. M. (2013). Fighting hunger together: A case of women farmers' participation in women groups in Mwala Division, Kenya. International Journal of Agricultural Management and Development (IJAMAD), 3(3), 189-200. 
Kasmiyati, \& Priyanti. (2014). Peran dan alokasi waktu tenaga kerja perempuan dalam usaha ternak sapi potong di Jawa Timur. Seminar Nasional Teknologi Peternakan dan Veteriner (pp. 278-288). Bogor: Litbang Pertanian.

Lesmana, D. (2005). Peranan wanita dalam pengambilan keputusan penerapan teknologi pada usahatani salak pondoh Nglumut. Jurnal EPP, 2(1), 29-38.

Manfre, C., Rubin, D., Allen, A., Summerfield, G., Colverson, K., \& Akeredolu, M. (2013). Reducing the Gender Gap in Agricultural Extension and Advisory Services: How to Find the Best Fit for Men and Women Farmers. Bangladesh: MEAS Project.

Notoatmojo, B. (2017). Peran gender dalam usahatani di kawasan Indonesia Bagian Timur. Journal The Winners, 2(2), 116129.

Othman, M. S., Oughton, E., \& Garrod, G. (2020). Significance of farming groups for resource access and livelihood improvement of rural smallholder women farmer. Development in Practice, 30(5), 586-598.

Puspitasari, N., Puspitawati, H., \& Herawati, T. (2013). Peran gender, kontribusi ekonomi perempuan, dan kesejahteraan keluarga petani hortikultura. Jurnal Ilmu Keluarga dan Konsumen, 6(1), 10-19.

Sari, R., Rosnita, \& Yulida, R. (2016). Faktorfaktor yang memengaruhi perilaku petani dalam menerima Program Kawasan Rumah Pangan Lestari (KRPL) di Kabupaten Pelalawan. SEPA, 13(1), 6377. Retrieved from https://jurnal.uns.ac.id/sepa/article/view/ $14242 / 11860$

Simon, H. A. (1993). Strategy and organizational evolution. Strategic Manajemen Journal, 14, 131-142.

SOFA-Team, \& Doss, C. (2011). The Role of Women in Agriculture. Rome: Agricultural Development Economics (ESA)-The Food and Agriculture Organization of the United Nations (FAO). 